\title{
Diferensiasi Otak Laki-laki dan Perempuan Guru Taman Kanak-kanak Aisyiyah Nyai Ahmad Dahlan Yogyakarta: Studi Pendidikan Islam Anak Usia Dini Perspektif Gender dan Neurosains
}

\author{
Suyadi \\ Universitas Ahmad Dahlan \\ email: suyadi@fai.uad.ac.id
}

\begin{abstract}
The male and female brains created by God are different. The existence of Islamic education specifically for men and women is a cultural construct. The existence of an attractive female-dominated teacher of Islamic Education Early Childhood (PIAUD) was investigated because it became a turning point in the formulation of gender studies between the emancipation of women and men. This study aims to explain the phenomenon of female teacher dominance in the perspective of gender and neuroscience. The research was conducted throughout 2017 at the TK Aisyiyah Nyai Ahmad Dahlan in Yogyakarta. This study used a qualitative approach, data collection techniques used observation, interviews, and documentation, while the triangulation analysis was carried out descriptively, comparatively and interpretatively. The results of the study showed that culturally sociological PIAUD teachers of TK Aisyiyah Nyai Ahmad Dahlan were 100\% female. But this female dominance is not a gender bias because neuro-physiologically the corpus callosum and broca and wernicke's Area in the female brain is thicker and wider than the male brain. This condition makes female teachers able to educate children more empathic and communicatively than men.
\end{abstract}

Keywords: maleand female brain; gender; neuroscience; Islamic Education Early Childhood

\begin{abstract}
Abstrak: Otak laki-laki dan perempuan diciptakan Tuhan memang berbeda. Adanya pendidikan Islam khusus laki-laki dan perempuan merupakan konstruk budaya. Keberadaan guru Pendidikan Islam Anak Usia Dini (PIAUD) yang didominasi perempuan menarik diteliti karena menjadi titik balik studi gender antara emansipasi wanita dan laki-laki. Penelitian ini bertujuan menjelaskan fenomena dominasi guru perempuan dalam perspektif gender dan neurosains. Penelitian dilakukan sepanjang tahun 2017 di TK Aisyiyah Nyai Ahmad Dahlan Yogyakarta. Penelitian ini menggunakan pendekatan kualitatif, teknik pengumpulan data menggunakan observasi, wawancara, dan dokumentasi, sedangkan analisis triangulasi dilakukan secara deskriptif, komparatif dan interpretatif. Hasil penelitian menunjukkan bahwa secara kultural sosiologis guru PIAUD TK Aisyiyah Nyai Ahmad Dahlan $100 \%$ perempuan. Namun dominasiperempuan ini bukan bias gender karena secara neuro
\end{abstract}


fisiologis corpus collasum dan area broca serta wernicke pada otak perempuan lebih tebal dan luas dari otak laki-laki. Kondisi ini menjadikan guru perempuan mampu mendidik anak-anak lebih empatik dan komunikatif daripada laki-laki.

Kata Kunci: otak laki-laki dan perempuan; gender; neurosains; Pendidikan Islam Anak Usia Dini

\section{A. Pendahuluan}

Penelitian tentang gender selama dasawarsa terakhir menunjukkan kemajuan yang signifikan. Hal ini ditunjukkan dengan tema-tema penelitian yang semakin luas, seperti pengarusutamaan gender di Saudi Arabia, Mesir, Malaysia dan Indonesia, ${ }^{1}$ tuntutan keadilan gender ${ }^{2}$ atau kesetaraan gender, ${ }^{3}$ pandangan Islam tentang gender ${ }^{4}$ hingga perspektif gender dalam pembelajaran. Perspektif gender juga mulai banyak digunakan dalam penelitian pembelajaran yang lebih spesifik, seperti kratifitas siswa dalam berpikir logis-matematis, ${ }^{5}$ bias gender

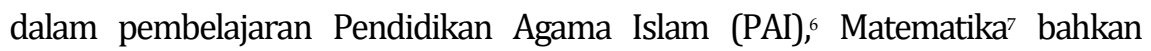
biologi. ${ }^{8}$

Penelitian di bidang neurosains (ilmu neural/sistem saraf/otak), juga menunjukkan kemajuan yang mencengangkan. Namun penelitian tentang otak dengan perspektif gender masih berhenti pada otak laki-laki dan perempuan

${ }^{1}$ Rohil Zilfa, "Telaah Komparatif Pengarusutamaan Gender dalam Pendidikan Islam di Saudi Arabia, Mesir, Malaysia, dan Indonesia," Jurnal Pendidikan Agama Islam 5, no. 2 (2017): 264-87.

${ }^{2}$ Nurazidawati Mohamad Arsad, "Peranan Bapak dalam Mewujudkan Keadilan Gender dalam Rumah Tangga: Islam dan Sains," Marwah:Jurnal Perempuan, Agama dan Jender 16, no. 2 (2017): 169-85.

3Zainal Abidin, "Kesetaraan Gender dan Emansipasi Perempuan dalam Pendidikan Islam," Tarbawiyah 12, no. 1 (2008): 1-18.

${ }^{4}$ Mahathir Muhammad Iqbal, "Diskusi Gender dalam Pendidikan Islam," Analisis: Jurnal Studi Keislaman 15, no. 1 (2015): 99-120.

${ }^{5}$ Dwi Novitasari, "Analisis Kreativitas Siswa dalam Pemecahan Masalah Visual Spasial dan Logis Matematis Ditinjau dari Gender," Jurnal Media Pendidikan Matematika (JMPM) 5, no. 2 (2017): 151-58.

${ }^{6}$ Mardin M. Nur, "Pengaruh Bias Gender Pembelajaran Pendidikan Agama Islam terhadap Ketidakadilan Gender di Madrasah Aliyah Ruhul Amin Aceh," Buana Gender 2, no. 2 (2017): 205-25, https://doi.org/10.22515/bg.v2i2.988.

7Zubaidah Amir MZ, "Perspektif Gender dalam Pembelajaran Matematika," Marwah 12, no. 1 (2013): 14-31; Siska Chindy Dilla, Wahyu Hidayat, dan Euis Eti Rohaeti, "Faktor Gender dan Resiliensi dalam Pencapaian Kemampuan Berpikir Kreatif Matematis Siswa SMA," Journal of Medives 2, no. 1 (2018): 129-36.

${ }^{8}$ Aloysius Durun Corebima Tarbawiyahrapto, Siti Zubaidah, "Pengaruh Gender terhadap Keterampilan Berpikir Kreatif Siswa pada Pembelajaran Biologi," Jurnal Pendidikan: Teori, Penelitian, dan Pengembangan 3, no. 3 (2018): 325-29. 
secara umum ${ }^{9}$ atau paling maju adalah bahasa perempuan dan laiki-laki. ${ }^{10}$ Adapun penelitian yang fokus pada otak guru perempuan belum banyak dilakukan.

Penelitian Purwanti tentang perbedaan gender dalam pembelajaran Matematika menggunakan otak kanan perlu mendapatkan perhatian khusus mengingat perspektif yang digunakan tidak sekadar gender, melainkan juga neurosains. Penelitian Purwanti tersebut menunjukkan bahwa kemampuan Matematika anak perempuan lebih tinggi daripada anak laki-laki. ${ }^{11}$

Penelitian dalam artikel ini berbeda dengan penelitian-penelitian di atas, namun memiliki keterkaitan erat dengan peneitian Purwanti. Perbedaannya, jika Purwanti meneliti perbedaan kemampuan Matematika anak laki-laki dan perempuan pada jenjang pendidikan dasar menggunakan otak kanan, penelitian ini meneliti otak guru PIAUD laki-laki dan perempuan dalam perspektif gender dan neurosains. Persoalan yang hendak dijawab dalam penelitian ini adalah mengapa 99 bahkan 100 persen guru anak usia dini adalah perempuan, dan apa implikasi dominasi perempuan dalam pendidikan anak usia dini tersebut?

Problem penelitian ini penting bahkan genting (urgen) untuk dijawab karena di luar dunia PAUD/PIAUD sedang hangat diperbincangkan tuntutan keadilan gender dan emansipasi wanita, sedangkan di PAUD/PIAUD justru terkesan menuntut "emansipasi laki-laki". Bila ada guru PIAUD laki-laki, maka akan dijadikan "polisi sekolah" terutama untuk menakut-nakuti peserta didik sebagaimana yang tejadi pada guru BK di sekolah.12 Bahkan, berbagai Program Studi Pendidikan Guru Pendidikan Anak Usia Dini (PG PAUD) atau Pendidikan

9Florian Kurth, Lutz Jancke, dan Eileen Luders, “Sexual Dimorphism of Broca's Region: More Gray Matter in Female Brains in Brodmann Areas 44 and 45," Journal of Neuroscience Research 95, no. August (2017): 626-32, https://doi.org/10.1002/jnr.23898; Dilansu Guneykaya et al., "Transcriptional and Translational Differences of Microglia from Male and Female Brains," Cell Reports 24, no. 10 (2018): 2773-2783.e6, https://doi.org/10.1016/j.celrep.2018.08.001.

${ }^{10}$ Jennifer Coates, Women, Men and Language (New York: Routledge Classics, 2016).

${ }^{11}$ Kristi Liani Purwanti, "Perbedaan Gender terhadap Kemampuan Berhitung Matematika Menggunakan Otak Kanan pada Siswa Kelas I," Sawwa: Jurnal Studi Gender 9, no. 1 (2013): 107-122, https://doi.org/10.21580/SA.V9I1.668.

12Suyadi dan Imam Zarkasih Putro, Bimbingan dan Konseling Pendidikan Anak Usia Dini (BKPAUD) (Bandung: Remaja Rosdakarya, 2016), 196. 
Islam Anak Usia Dini (PIAUD) selalu didominasi perempuan. Memang terdapat segelintir mahasiswa pada prodi tersebut namun mereka merasa inlander. Hingga saat ini masih langka guru PAUD/PIAUD laki-laki.

Untuk menjawab problem tersebut, dilakukan penelitian kualitatif dalam bentuk field research. ${ }^{13}$ Setting penelitian adalah TK Aisyiyah Nyai Ahmad Dahlan yang beralamatkan di Pilahan, Kotagede Yogyakarta. Penelitian dilakukan sepanjang tahun 2017. Teknik pengumpulan data dilakukan dengan observasi, wawancara dan dokumentasi. Analisis triangulasi data dilakukan secara deskriptif, interpretatif dan komparatif mengikuti model Denzin dan Lincoln. ${ }^{14}$

Tujuan penelitian ini adalah menemukan penjelasan yang clear dan clean mengapa guru PAUD/PIAUD "harus" perempuan. Penjelasan tersebut tidak hanya membutuhkan satu pendekatan keilmuan semata, melaikan lintas bidang ilmu yang diintegrasikan sehingga multi perspektif, yakni gender, neurosins dan al-Qur'an. Perspektif gender diperlukan karena memang guru PIUAD didominasi perempuan, perpektif neurosains diperlukan karena neurofisiologi otak perepuan dan laki-laki berbeda, dan pespektif al-Qur'an perlu diterapkan karena setting penelitian adalah PAUD berbais Islam (PIAUD).

\section{B. Otak Laki-laki dan Otak Perempuan}

Otak merupakan permata dari mahkota tubuh manusia. ${ }^{15}$ Dalam perspektif gender, neuroanatomi (struktur organ biologis) ${ }^{16}$ otak laki-laki dan perempuan tidak banyak berbeda, kecuali dua hal, yakni corpus callosum dan area broca-wernicke. Dengan demikian, neuroanatomi otak laki-laki dan perempuan lebih banyak persamaannya daripada perbedaannya. Perbedaan corpus callosum dan area broca-wernicke membawa konsekuensi fungsi otak laki-laki dalam berpikir. Berikut dikemukakan neuroanatomi otak, baik laki-laki maupun perempuan secara umum, kemudian dikhususkan pada perbedaan pada dua hal tersebut, yakni Corpus callosum dan area broca-wernicke.

\footnotetext{
${ }^{13}$ Lexy J Moleong, Metodologi Penelitian Kualitatif(Bandung: Remaja Rosdakarya, 2014), 74.

${ }^{14}$ Norman K. Denzin dan Yvonna S. Lincoln, Handbook of Qualitative Research, 2 ed. (India: Sage Publication. Pvt. Ltd, 1997), 196.

${ }^{15}$ Taruna Ikrar, Ilmu Neurosains Modern (Yogyakarta: Pustaka Pelajar, 2016), 1.

${ }^{16}$ Richard S. Snell, Clinical Neuroanatomy, 7th Edition, Statistical Science (China, 2010), 7.
} 


\section{Neuroanatomi Otak}

Banyak pakar neurosaintis yang membagi anatomi otak berbeda-beda. David A Souasa membagi anatomi otak menjadi tiga, yakni otak besar, otak kecil dan otak tengah. ${ }^{17}$ Taufiq Pasiak juga membagi otak menjadi tiga, yakni otak depan, otak belakang dan otak tengah. ${ }^{18}$ Taruna Ikrar juga membagi anatomi otak menjadi tiga, yakni otak belakang, otak depan dan otak tengah. Ketiganya sama, yang membedakan hanya posisi anatomi satu dengan yang lain.

Otak tengah yang dimaksud para neurosaintis di sini bukanlah otak tengah seperti yang dimaksud para motivator dalam buku-buku populer yang terksan magij atau tidak ilmiah. Otak kanan yang dimaksud para neurosaintis di sini juga berbeda dengan "otak kanan" sebagaimana yang dimaksud para motivator aktivasi otak kanan yang bertebaran dalam buku-buku populer.

Peneliti cenderung merujuk pada pembagian anatomi otak Taufiq Pasiak dengan pertimbangan bahwa anatomi ini lebih mudah dilakukan kajian interdisipliner, khususnya perspektif pendidikan Islam. ${ }^{19}$ Atas dasar ini pula, anatomi tersebut akan menjadi acuan dalam penelitian ini, khususnya keterkaitannya dengan perspektif al-Qur'an.

Peneliti perlu meluruskan adanya oversimplivikasi yang membagi anatomi otak hanya menjadi dua, yakni otak kanan dan otak kiri. Pembagian anatomi otak menjadi dua, yakni hemisfer kiri dan kakan tersebut bersumber pada Roger Sperry tapi khusus otak besar (dalam istilah David A Sousa) atau otak depan dalam istilah Taufiq Pasiak. Dengan demikian, anatomi otak yang dibagi mejadi dua tersebut hanyalah otak besar atau otak depan, bukan keseluruhan otak itu sendiri.

Peneliti juga mengutip pendapat Hebb yang menyatakan bahwa oversimplifikasi hemisferik otak kanan dan kiri tidaklah seperti yang tertera dalam buku-buku populer di atas. ${ }^{20}$ Dikatakan bahwa fungsi otak kiri adalah berpikir

\footnotetext{
${ }^{17}$ David A. Sousa, Bagaimana Otak Belajar Edisi Keempat (Jakarta: Indeks, 2012), 13.

${ }^{18}$ Taufiq Pasiak, Tuhan dalam Otak Manusia: Mewujudkan Kesehatan Spiritual Berdasarkan Neurosains (Bandung: Mizan, 2012), $16 .$.

${ }^{19}$ Suyadi, "Dasar-dasar Pemikiran menuju Ilmu Neurosains Pendidikan Islam (Optimalisasi Potensi Otak dalam Pembelajaran Anak Usia Dini)” (Disertasi, Pascasarjana UIN Sunan Kalijaga, 2016), http://digilib.uin-suka.acid/19927/.

${ }^{20}$ Suyadi, Teori Pembelajaran Anak usia Dini dalam Kajian Neurosains (Bandung: Rosda Karya, 2016), 70-1.
} 
kritis, logis, sistematis dan linier; sedangkan otak kanan berpikir holistik, integratif, estetik dan difergen, tidak selalu benar. ${ }^{21}$ Pasalanya, teori neuroplastisitas menunjukkan bahwa otak kiri juga dapat berpikir holistik demikian pula sebaliknya, otak kanan juga dapat berpikir kritis. ${ }^{22}$ Jika tidak demikian, maka akan muncul postulat yang kurang tepat beranggapan bahwa seniman dan musisi hanya bekerja dengan otak kanan sedangkan ilmuwan hanya berpikir menggunakan otak kiri.

Pandangan-pandangan populer tentang otak, termasuk metode otak kanan yang diteliti Purwanti, ${ }^{23}$ terlebih lagi "otak tengah" dan atau otak kanan secara umum ${ }^{24}$ merupakan pendapat-pendapat dalam buku populer yang tidak dapat dipertanggung jawabkan kebenarannya secara ilmiah.

\section{Corpus Callosum pada Otak Laki-laki dan Perempuan}

Corpus collasum merupakan bagian otak yang bentuknya menyerupai pita tebal, letaknya di antara otak besar dan sistem limbik. ${ }^{25}$ Fungsi corpus collasum adalah menghubungkan otak kiri dan kanan dengan sistem limbik yang meregulasi emosi, sehingga otak dapat bekerja secara holistik. Keberadaan corpus callosum ini turut memperkuat kritik Hebb tentang oversimplivikasi otak kiri dan kanan.26

Corpus collasum menjadi jalur pita informasi dari hemisfer kiri dan kanan secara bolak-balik. Pikiran kritis, sistematis dan logis dari otak kiri akan dipertimbangkan aspek etika, estetika, dan holistikanya oleh otak kanan. Demikian pula sebaliknya, pikiran etis, estetis dan holistik dari otak kanan akan dicerna atau diurai secara kritis, sistematis dan logis oleh otak kiri.

\footnotetext{
${ }^{21}$ Donald Olding Hebb, "Teori Neurofisiologis Dominan," dalam Theories of Learning, ed. B.R. Hergenhahn dan Matthew H. Olson (Jakarta: Kencana, 2012), 418.

${ }^{22}$ Lauren M. DePoy dan Shannon L. Gourley, "Synaptic Cytoskeletal Plasticity in the Prefrontal Cortex Following Psychostimulant Exposure," Traffic 16, no. 9 (2015): 919-40, https://doi.org/ 10.1111/tra.12295.

${ }^{23}$ Purwanti, "Perbedaan Gender terhadap Kemampuan Berhitung Matematika ....”

${ }^{24}$ Ippo 'Right' Santosa, Seri Otak Kanan; 7 Keajaiban Rejeki (Jakarta: PT. Elek Media Komputindo, 2012), 50-1.

${ }^{25}$ Fabienne Cyprien et al., "Corpus callosum size may predict late-life depression in women: A 10year follow-up study," Journal of Affective Disorders 165, no. August (2014): 16-23, https://doi.org/10.1016/j.jad.2014.04.040.

26Donald Olding Hebb, "Teori Neurofisiologis Dominan." 419.
} 
Jika salah satu belahan otak mengalami gangguan, maka belahan lain akan menggantikan fungsi otak tersebut. Inilah yang disebut dengan teori plastisity, yakni perubahan fungsi bagian otak tertentu akibat disfungsi bagian otak yang lain. ${ }^{27}$ Gambar 1 merupakan gambar corpus callosum yang dimaksud.

Corpus collasum sebagaimana ditunjukan Gambar 1 pada perempuan lebih tebal daripada laki-laki. Konsekuensinya, perempuan dapat mengerjakan lebih banyak hal secara bersamaan daripada laki-laki.28 Sekadar contoh guru PAUD/PIAUD perempuan dapat menyelesaikan banyak pekerjaan sekolah secara bersamaan, seperti ketika mengajar dapat menulis, menggambar, dan bercerita sekaligus, bahkan masih sempat mengerjakan administrasi sekolah. Sebaliknya, guru PAUD/PIAUD laki-laki umumnya menulis terlebih dahulu kemudian menjelaskan kepada anak didik atau menggambar terlebih dahulu kemudian bercerita.

Sebaliknya, corpus callosum pada laki-laki yang lebih tipis daripada perempuan mengkondisikan laki-laki sulit melakukan banyak hal dalam waktu

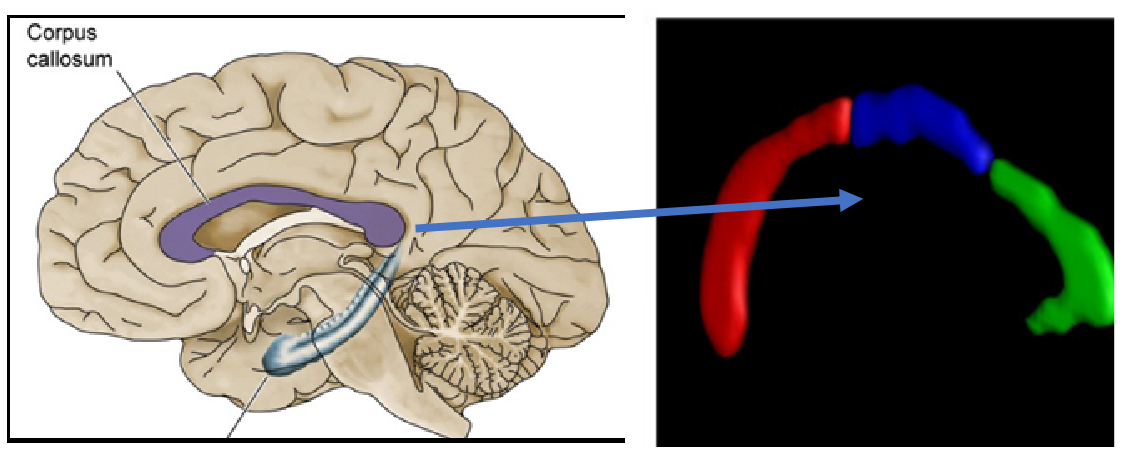

Gambar 1.

Corpus callosum ${ }^{29}$

27DePoy dan Gourley, “Synaptic Cytoskeletal Plasticity ....", 5.

${ }^{28}$ Sharlene D. Newman, "Differences in Cognitive Ability and Apparent Sex Differences in Corpus Callosum Size," Psychological Research 15, no. 3 (2015): 10-15, https://doi.org/10.1007/s00426-0150688-3.

${ }^{29}$ Cyprien et al., "Corpus callosum size may predict late-life depression in women: A 10-year follow-up study." 
yang bersamaan. Sekadar contoh, jika guru PAUD/PIAUD laki-laki sedang membaca, maka Ia sulit dapat melakukan pekerjaan lain, meskipun sekadar menjaga anak didiknya bermain. Lain halnya dengan perempuan, menjaga anak-anak dapat dilakukan dengan pekerjaan-pekerjaan lainnya, seperti menyusun RPP, adimistrasi sekolah dan pekerjaan lainnya. Meskipun demikian, kondisi ini justru menguntungkan laki-laki karena mudah fokus dalam mencapai tujuan tertenti. Oleh karena itu, jika guru PAUD/PIAUD lakilaki menjadi kepala sekolah, maka visinya lebih kepada perluasan atau memperbesar kapasitas sekolah daripada menyelesaikan persoalan internal.

Corpus collasum merupakan bagian dari limbik sistem yang justru terlihat aktif ketika istirahat, khususnya otak perempuan. Adapun pada otak laki-laki, aktivitas otak yang lebih aktif ketika istirahat adalah limbik temporal. ${ }^{30}$ Secara evolutif, corpus callosum merupakan perkembangan sistem limbik, sedangkan limbik temporal merupakan perkembangan otak kecil. Akan tetapi, keduanya (corpus callosum dan sistem limbik) sama-sama meregulasi ekspresi emosi.

Secara fisiologis, corpus callosum lebih banyak meregulasi perilaku emosional, khususnya mengekspresikan sikap fleksibilitas, kerjasama, dan deteksi kesalahan (introspektif). ${ }^{31}$ Gangguan pada corpus callosum dapat mengakibatkan letupan emosi yang kurang terkendali, seperti dendam berkepanjangan, kompulsif, menyalahkan orang lain, atau sekadar marah seraya membelalakkan mata, dan ekspresi motorik lainnya.

Penjelasan neuroanatomi dan neurofisiologi corpus callosum di atas relevan dengan penelitian Ratnasari yang menyatakan bahwa terdapat perbedaan antara regulasi emosi pada laki-laki dan perempuan. Menurut Ratnasari, perempuan lebih mampu mengontrol emosi daripada laki-laki. Atas dasar ini dapat diketahui bahwa guru PAUD/PIAUD perempuan lebih dapat mengontrol emosi ketika berhadapan dengan anak usia dini. ${ }^{32}$

\footnotetext{
${ }^{30}$ Taufiq Pasiak, Revolusi IQ/EQ/SQ: Menyingkap Rahasia Kecerdasan Berdasarkan al-Qur'an dan Neurosains Mutakhir (Bandung: Mizan Bandung, 2008), 280.

31Taufiq Pasiak, "Pendidikan Karakter sebagai Pendidikan Otak," dalam Mengatasi Masalah Narkoba dengan Welas Asih (Jakarta: Gramedia Pustaka Utama, 2012), 190-2.

${ }^{32}$ Shinantya Ratnasari dan Julia Suleeman, "Perbedaan Regulasi Emosi Perempuan dan Laki-laki di Perguruan Tinggi," Jurnal Psikologi Sosial 15, no. 1 (2017): 35-46, https://doi.org/10.7454/ jps.2017.4.
} 


\section{Area Broca dan Wernicke pada Otak Laki-laki dan Perempuan}

Area broca dan wernicke pada otak manusia ditemukan oleh Paul Broca, ahli saraf dari Prancis ketika meneliti otak pasien yang mengalami gangguan bahasa. Sedangkan area wernicke ditemukan oleh carl wernicke, ahli saraf dari jerman ketika meneliti pasian dengan gejala serupa dengan gangguan bahasa. ${ }^{33}$ jadi, istilah broca dan wernicke pada otak manusia diambil dari nama penemunya sendiri.

Area broca merupakan bagian otak manusia yang terletak pada lobus prefrontal sebelah kiri. ${ }^{34}$ Area broca juga berdekatan dengan area wernicke yang secara umum hanya ada di hemisfer kiri. Area ini berfungsi meregulasi pemrosesan bahasa serta memahami aspek berbicara. Area broca dan wernicke dihubungkan oleh jalur saraf yang disebut. ${ }^{35}$ Organ biologis ini bertanggung jawab meregulasi bahasa dan pemahaman pembicaraan.

Gangguan pada area broca dan wernicke dapat menyebabkan yang bersangkutan mengalami gangguan berbahasa, seperti gagap bicara atau gangguan lain yang sejenisnya. ${ }^{36}$ Namun demikian, Rutten mengktirik doktrin area broca dan wernicke ini karena beberapa kasus pasien yang mengalami gangguan broca masih bisa berbicara dengan lancar. Hal ini menunjukkan bahwa bahasa tidak satu-satunya diregulasi area broca dan wernicke, melainkan diproses bagian otak yang lain ketika broca mengalami gangguan.

Area broca pada perempuan lebih luas daripada laki-laki. Hal ini berimplikasi pada penguasaan bahasa dan pemahaman artikulasi kata lebih baik daripada laki-laki. Adi W Gunawan juga meyebutkan bahwa setiap hari (24 jam) laki-laki hanya memiliki cadangan kata sebanyak 12.000 kata, sedangkan perempuan memiliki lebih dari 25.000 kata. Oleh karena itu "label" cerewet atau banyak bicara lebih banyak disandang perempuan daripada laki-laki.

\footnotetext{
${ }^{33}$ Arthur W Toga dan Paul M Thompson, "Mapping Brain Asymmetry," Nature Review Neuroscience 4, no. January (2003): 33-46, https://doi.org/10.1038/nrn1009.

${ }^{34}$ D Avid S Heyn, T O N Y S Heyn, dan G Abrielle M D E C Ourten Yers, "Structure of the Cerebral Cortex in Men and Women," Journal of Neuropathology and Experimental Neurology 61, no. 1 (2002): 46-57.

${ }^{35}$ Snell, Clinical Neuroanatomy, 7th Edition.

36Jay Desai et al., "Reduced Perfusion in Broca's Area in Developmental Stuttering," Human Brain Mapping 38, no. November 2016 (2017): 1865-74, https://doi.org/10.1002/hbm.23487.
} 
Dalam konteks guru PAUD/PIAUD yang secara teknis "pekerjaannya" berbicara (mendidik dengan metode dongeng, misalnya), maka guru PAUD/ PIAUD perempuan lebih diuntungkan daripada laki-laki. Bagi guru perempuan, semakin banyak bercerita semakin menyenangkan. Sebaliknya, laki-laki cenderung pendiam dan hanya akan bicara jika diperlukan. Adapun jika terdapat pendongeng anak atau pembicara unggul bukan perempuan melainkan lakilaki, Kak Bimo, ${ }^{37}$ misalnya, maka hal itu merupakan profesi yang telah dilatih secara profesional. Jika perempuan dilatih secara profesional untuk menjadi pendongeng atau pembicara ungggul, tentu lebih menguntungkan.

Luasnya area broca para otak guru PAUD/PIAUD perempuan sehingga memiliki keterampilan berbicara lebih unggul tidak hanya menguntungkan bagi diri guru itu sendiri, melainkan juga menguntungkan bagi anak didik. Hal ini disebabkan karena perkembangan bahasa anak usia dini ${ }^{38}$ secara umum sedang memasuki jendela kesempatan ${ }^{39}$ atau masa peka (sensitif period) bahasa atau language sensitive period. ${ }^{40}$

Anak-anak yang sedang memasuki masa peka bahasa (banyak bertanya atau bicara), kemudian dididik oleh guru PAUD/PIAUD perempuan yang juga banyak bicara, maka akan semakin mempercepat capaian perkembangan bahasa anak. Dengan demikian, dalam perspektif neurosains, khususnya area broca dan wernicke, guru PAUD perempuan bukan bias gender melainkan telah menjadi sunnatullāh.

\section{Guru PIAUD Perempuan di TK Aisyiyah Nyai Ahmad Dahlan Yogyakarta}

TK Aisyiyah Nyai Ahmad Dahlan adalah salah satu bentuk Pendidikan Anak Usia Dini (PAUD) jalur formal. ${ }^{41}$ Dalam pandangan Ahmad Tafsir, TK ini merupakan salah satu bentuk pendidikan Islam, tepatnya sekolah bercirikhas

${ }^{37}$ Kak Bimo, Mahir Mendongeng (Yogyakarta: Pro-U Media, 2011), 14.

${ }^{38}$ Suyadi, Psikologi Belajar PAUD (Yogyakarta: Pedagogia, 2009), 218.

${ }^{39}$ David A. Sousa, Bagaimana Otak Belajar Edisi Keempat.

${ }^{40}$ William Crain, Teori Perkembangan, Konsep dan Aplikasi, Trj. Yudi Santoso (Yogyakarta: Pustaka Pelajar, 2007), 137.

41Suyadi dan Maulidya Ulfa, Konsep Dasar PAUD (Bandung: Remaja Rosdakarya, 2013), 21. 
Islam. ${ }^{42}$ Bentuk pendidikan Islam lainnya dapat berupa pesantren (lembaga pendidikan Islam khas Indonesia) atau madrasah. Kurikulum yang berlaku di TK Aisyiyah Nyai Ahmad Dahlan adalah kombinasi antara kurikulum 2013 PAUD ${ }^{43}$ dan kurikulum ke-Aisyiyah-an. Kurikulum ke-Aisyiyah-an adalah kurikulum pendidikan Islam itu sendiri, ${ }^{44}$ yaitu kurikulum yang disusun berdasarkan al-Qur'an dan Sunnah.

TK yang berdiri sejak 2004 ini telah berkemban pesat dengan membuka program full day. TK ini memiliki guru sejumlah 17 dan tenaga pendidik 8 orang serta peserta didik sebanyak 140 anak. ${ }^{45}$ TK ini juga memiliki sarana prasarana sangat memadai bahkan memiliki keunggulan sarpras yang tidak dimiliki oleh TK lain, yakni dua kolam renang anak yang terpisah untuk laki-laki dan perempuan.

Gambar 2 menunjukkan bahwa TK Aisyiyah Nyai Ahmad Dahlan sangat merespon bias gender. Ditinjau dari sisi kolam renang ini saja, TK ini sudah menerapkan asas-asas Islami, yakni mengajarkan renang sebagaimana hadis nabi dan memisahkan antara laki-laki dan perempuan.

$$
\text { قال رسول الله صلى الله عليه وسلم: علموا أبناءكم السباحة والرماية .... }
$$

Rasulullah bersabda: "Ajarilah anak-anakmu berenang dan memanah..." (HR. al-Ṭahawi)

Hadis riwayat al-Tahawi di atas menjadi dasar bagi TK Aisyiyah Nyai Ahmad Dahlan dalam membuat kolam. Setiap anak didik diajarkan renang satu minggu sekali. Dengan demikian, kedua kolam renang di atas berfungsi setiap hari secara bergantian.

Penelitian Purwanti yang menyatakan bahwa anak perempuan lebih unggul kemampuan matematikanya daripada anak laki-laki menarik untuk di2014), 12.

${ }^{42}$ Ahmad Tafsir, Ilmu Pendidikan dalam Perspektif Islam, Revisi (Bandung: Remaja Rosdakarya, 2014), 78.

43Suyadi dan Dahlia, Implementasi dan Inovasi kurikulum PAUD 2013 (Bandung: Rosda Karya,

${ }^{44}$ Yunus Mustaqim, "Pengembangan Konsepsi Kurikulum dalam Pendidikan Islam," Edukasia: Jurnal Penelitian Pendidikan Islam 9, no. 1 (26 Maret 2014): 1-24, https://doi.org/10.21043/ edukasia.v9i1.761.

45Tim Penyusun, Profil TK Aisyiyah Nyai Ahmad Dahlan Full Day (Yogyakarta: Aisyiyah, 2018), 1-5. 

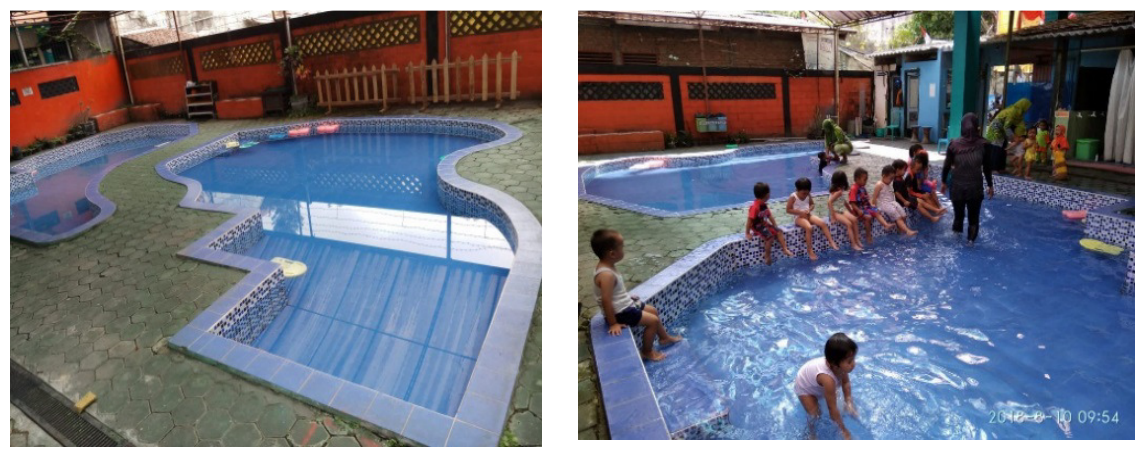

Gambar 2.

Kolam Renang Anak Perempuan dan Laki-laki di

TK Aisyiyah Nyai Ahmad Dahlan Yogyakarta

analisis lebih lanjut, apakah guru perempuan juga lebih unggul kemampuan matematikanya daripada guru laki-laki dan apakah keunggulan tersebut hanya di bidang matematika serta tidak berlaku pada bidang yang lain? Jika kemampuan akademik anak perempuan, terutama pada jenjang pendidikan dasar lebih unggul daripada anak laki-laki, mengapa jumlah perempuan yang menempuh jenjang pendidikan tinggi, semain termarjinalkan?

Observasi peneliti di TK Aisyiyah Nyai Ahmad Dahlan menunjukkan bahwa jumlah guru adalah 17 dan perempuan semua (100\% perempuan). Laki-laki satu-satunya di TK Aisyiyah Ahmad Dahlan adalah Satpam. Beberapa TK lain di Yogyakarta juga menunjukkan fenomana serupa, yakni antara 99\% atau $100 \%$ perempuan. ${ }^{46}$ Data para Guru di TK Aisyyah Nyai Ahmad Dahlan dapat dilihat pada Tabel 1.

Tabel 1. menunjukkan bahwa 100\% guru TK Aisyiyah Nyai Ahmad Dahlan adalah perempuan. Jumlah ini menarik jika dicermati dalam konteks sejumlah kebijakan, misalnya, jumlah anggota Dewan Perwakilan Rakyat, minimal $30 \%$ adalah perempuan. ${ }^{47}$ Kebijakan ini baru tercapai antara $10-15 \%$

${ }^{46}$ Suyadi, “Dasar-dasar Pemikiran menuju Ilmu Neurosains Pendidikan Islam..." 158-160.

${ }^{47}$ Lies Ariany, "Partisipasi Perempuan di Legislatif Melalui Kuota 30\% Keterwakilan Perempuan di Provinsi Kalimantan Selatan," Jurnal Konstitusi 2, no. 1 (2009): 47-61. 
Tabel 1.

Guru TK Aisyiyah Nyai Ahmad Dahlan

\begin{tabular}{clcc}
\hline \multirow{2}{*}{ No } & \multicolumn{1}{c}{ Nama Guru } & \multicolumn{2}{c}{ Jenis Kelamin } \\
& & - & Perempuan \\
\hline 1 & Nawarol Muniroh, S.TP & - & $\mathrm{V}$ \\
2 & Ridawati, A. Md. & - & $\mathrm{V}$ \\
3 & Neti Wuryani & - & $\mathrm{V}$ \\
4 & Sukraeni, S.Pd.AUD. & - & $\mathrm{V}$ \\
5 & Windriyatni, S.Pd. & - & $\mathrm{V}$ \\
6 & lid Maida Rais, S.Kh. & - & $\mathrm{V}$ \\
7 & Umi Masamah, S.Pd.I. & - & $\mathrm{V}$ \\
8 & Laily Widhiastuti, S.Psi. & - & $\mathrm{V}$ \\
9 & Utami Mayawardhani, S,Si. & - & $\mathrm{V}$ \\
10 & Susi Retnowati, S.Pd. AUD. & - & $\mathrm{V}$ \\
11 & Alfia Trimaylansari, S.Psi. & - & $\mathrm{V}$ \\
12 & Anisa Tulhijriyah & - & $\mathrm{V}$ \\
13 & Septiana Abadi, S.Sos.I. & - & $\mathrm{V}$ \\
14 & Fardani Atina Yekti, S.Pd.I. & - & $\mathrm{V}$ \\
15 & Walijah & - & $\mathrm{V}$ \\
16 & Arroyan Amri Sakinah, S.Sos.I. & - & $\mathrm{V}$ \\
17 & Asri Wulandari, S.Pd. & & $\mathrm{V}$ \\
\hline
\end{tabular}

dan belum merata di seluruh Indonesia. Oleh karena itu, jika ada perwakilan guru PAUD/PIAUD perempuan yang mencalonkan diri sebagai anggota legislatif di parlemen, kemungkinan besar akan mendapat dukungan suara yang memadai dari persatuan guru PAUD/PIAUD perempuan yang selama ini tergabung dalam wadah Himpunan Pendidikan Anak Usia Dini Indonesia (HIMPAUDI).

Fakta pada Tabel 1. juga dapat menjadi inspirasi bagi penyelesaian masalah tentang pergulatan wacana kepemimpinan perempuan di kalangan Nahdlatul Ulama (NU) yang hingga kini belum mendapatkan pencerahan. ${ }^{48}$ Artinya, mengingat seluruh guru, termasuk kepala sekolah (pemimpin sekolah) di PAUD/PIAUD adalah perempuan, maka wacana tersebut dapat diklarifikasi dengan realitas yang ada. Data dalam Tabel 1. juga menarik untuk diklarifikasi dengan penelitian Zainal Abidin yang masih menuntut kesetaraan gender dan emansipasi perempuan dalam pendidikan Islam ${ }^{49}$ dan penelitian Aris Try

${ }^{48}$ Jamal Ma'mur Asmani, “Kepemimpinan Perempuan: Pergulatan Wacana di Nahdlatul Ulama (NU)," Addin 9, no. 1 (2015):33-50.

${ }^{49}$ Abidin, "Kesetaraan Gender dan Emansipasi Perempuan dalam Pendidikan Islam." 
Andreas Putra yang masih mempersoalkan pendidikan kaum perempuan.50 Kedua penelitian ini jelas kurang relevan bagi TK Aisyiyah Nyai Ahmad Dahlan $100 \%$ gurunya adalah perempuan. Dengan kata lain, fakta $100 \%$ guru PAUD di atas sedikit atau banyak telah menjadi jawaban atas tuntutan kesetaraan gender.

Fenomena 100\% guru PAUD/PIAUD perempuan sebenarnya tidak hanya di lingkungan guru-guru PAUD. Belakangan ini mulai berkembang komunitas perempuan, salah satunya adalah komunitas "Saya Perempuan Anti Korupsi (SPAK)".51 SPAK adalah komuntas yang dirancang oleh Komisi Pemberantasan Korupsi (KPK) agar para istri dapat menjadi penjaga moral keluarga dan suami. Mengadaptasi desain KPK ini, guru PAUD/PIAUD perempuan, seharusnya dapat mejadi benteng bagi keluarga, menjaga anak-anak dari kebodohan dan karakter kecendekiawanan suami.

Fakta lain menunjukkan hal yang memprihatinkan, bahwa semakin tinggi jenjang pendidikan, perempuan semakin termarjinalkan. Perempuan yang menempuh jenjang pendidikan sarja (S1) memang relatif berimbang dengan laki-laki., tetapi perempuan yang menempuh penjang magister (S2) sudah mulai berkurang, sedangkan perempuan yang menempuh jenjang pendidikan Doktor (S3) sangat sedikit. ${ }^{52}$ Padahal, kemampuan akademik tertinggi dicapai pada jenjang doktoral.

Hingga saat ini jumlah guru PAUD/PIAUD berkualifikasi pendidikan sarjana (S1) belum menyeluruh. Guru PAUD/PIAUD berkulifikasi S1 terbanyak adalah Yogyakarta, termasuk TK 'Aisyiyah Nyai Ahmad Dahlan yang 98\% gurunya telah berkulifikasi S1. Tetapi di daerah lain, terlebih lagi kepualauan Terluar, Terdepan dan Tertinggal (3T), guru PAUD/PIAUD hanyalah ibu-ibu pengangguran yang menjadikan kegiatan pembelajaran anak usia dini sebagai pekerjaan sambilan.

Kebijakan Menteri Pendidikan dan Kebudayaan hanya mensyaratkan guru PAUD/PIAUD cukup berkualifikasi S1. Kebijakan ini sangat berbeda

${ }^{50}$ Aris Try Andreas Putra, "Peran Gender dalam Pendidikan Islam," Jurnal Pendidikan Islam 3, no. 2 (2014):327-43, https://doi.org/10.14421/jpi.2014.32.325-343.

51Fitri Yuliantri Permana, "Perempuan dalam Kampanye Antikorupsi," Jurnal Aspikom 3, no. 3 (2016): 399-413.

${ }^{52}$ Suyadi dan Ulfa, Konsep Dasar PAUD, 164-9. 
dengan pemerintah Jepang yang mensyaratkan setiap lembaga PAUD harus memiliki guru yang berkualifikasi akademik S3. Di Indonesia, laki-laki dan perempuan yang berpendidikan S3 biasanya tidak lagi mau menjadi guru PAUD kemudian pindah menjadi dosen di Perguruan Tinggi. Akibatnya, Guruguru perempuan yang mengajar pada jenjang PAUD/PIAUD belum memadai untuk mendidik anak usia dini, terlebih lagi anak-anak perempuan yang memiliki kemampuan akademik lebih unggul dari laki-laki.

Corpus callosum perempuan yang ternyata lebih tebal daripada laki-laki dapat menjelaskan keunggulan guru PAUD/PIAUD perempuan daripada lakilaki. Namun corpus callosum tidak meregulasi kemampuan akademik, melainkan mengatur keterampilan regulasi emosi. Oleh karena itu, peneliti berpendapat bahwa kemampuan regulasi emosi yang stabil dapat berpengaruh pada kemampuan Matematika pada anak perempuan.

Adapun area broca dan wernicke pada perempuan yang lebih luas daripada laki-laki sehingga kapasitas bahasa perempuan lebih kompleks daripada laki-laki juga dapat memperkuat fenomena 100\% guru PAUD/PIAUD perempuan. Artinya, kompleksitas bahasa dengan kekayaan kosakata yang memadai dimungkinkan dapat meningkatkan kemampuan matematika anak.

Muniroh, kepala TK Aisyiyah Nyai Ahmad Dahlan mengatakan, "Semua guru di sini perempuan, yang laki-laki hanya satpam. Ibu-ibu lebih sabar dan penyayang pada anak-anak." Pernyataan kepala TK Aisyiyah Nyai Ahmad Dahlan di atas menarik untuk dicermati dalam persktif neurosains. Istilah sabar dan kasih sayang merupakan kemampuan meregulasi emosi tingkat tinggi.

Dengan demikian, dapat dipahami bahwa guru PAUD/PIAUD perempuan di TK Aisyiyah Nyai Ahmad Dahlan khususnya atau lembaga PAUD/PAID umumnya belum dapat dikatakan ideal jika belum berkualifikasi S3 atau doktor. Keberadaan guru PAUD perempuan di TK Aisyiyah Nyai Ahmad Dahlan lebih disebabkan karena faktor "ketersediaan", yakni adanya memang hanya sarjana perempuan dan tidak ada ada sarjana laki-laki yang berminat menjadi guru PAUD.

Laki-laki yang berkualifikasi pendidikan sarjana AUD (Anak Usia Dini) pada umumnya lebih berminat menjadi trainer atau motivator bagi guru-guru PAUD/PIAUD daripada guru PAUD itu sendiri. Terlebih lagi jika ada laki-laki 
yang berpendidikan S2 dan S3 PAUD, tetap tidak mau menjadi guru PAUD, melainkan dosen PAUD. Dengan demikian, keberadaan guru PAUD perempuan di TK Aisyiyah Nyai Ahmad Dahlan belum menunjukkan keunggulannya yang signifikan daripada guru PAUD/PIAUD laki-laki (jika ada), kecuali dalam hal regulasi emosi yang lebih matang. Guru PAUD/PIAUD perempuan lebih penyabar dan terampil mendidik anak-anak dengan kasih sayang yang lebih empatik.

\section{Otak Guru PIAUD Perempuan di TK Aisyiyah Nyai Ahmad Dahlan Yogyakarta}

Laki-laki dan perempuan tidak hanya berbeda jenis kelamin dan seluruh anggota tubuhnya,,53 melainkan juga termasuk otaknya. Ukuran otak laki-laki umumnya 12 persen dari berat badannya sedangkan ukuran otak perempuan 1 persen dari laki-laki, dan ukuran lingkar kepala wanita biasanya dua persen lebih kecil dari laki-laki. ${ }^{54}$ Informasi ini tidak serta merta laki-laki lebih cerdas daripada wanita, karena kecerdasan tidak ditentukan semata-mata oleh ukuran otak dan lingkar kepala, melainkan jumlah jaringan neuron yang terhubung satu-sama lain dan membentuk simpul-simpul pengetahuan di dalam otaknya. ${ }^{55}$ Meskipun demikian penelitian Corral-López menunjukkan bahwa ukuran otak perempuan mempengaruhi kemampuan kognisisnya. ${ }^{56}$ Artinya, ukuran otak laki-laki juga berpengaruh pada kemampuan kognisinya, sehingga keunggulan otak perempuan dan laki-laki tidak dapat diukur dengan volume otaknya.

Sebagaimana bahwa corpus callosum pada perempuan lebih tebal daripada laki-laki. Hal ini mengindikasikan bahwa perempuan dapat mencerna informasi dari hemisfer kiri dan kanan lebih cepat daripada laki-laki. Perbedaan lainnya adalah, laki-laki lebih banyak mengontrol informasi pada otak kiri sedangkan perempuan memiliki kontrol lebih besar pada otak kanan.

\footnotetext{
${ }^{53}$ Geert J De Vries dan Nancy G Forger, "Sex Differences in the Brain: A Whole Body Perspective," Biology of Sex Differences 5, no. 15 (2015): 1-15, https://doi.org/10.1186/s13293-015-0032-z.

${ }^{54}$ Alexander Kotrschal et al., "Brain Size Affects Female but not Male Survival under Predation Threat," Ecology Letters 18, no. 7 (2015): 646-52, https://doi.org/10.1111/ele.12441.

${ }^{55}$ Suyadi, Teori Pembelajaran Anak usia Dini dalam Kajian Neurosains, 61.

${ }^{56}$ Alberto Corral-López et al., "Female brain size affects the assessment of male attractiveness during mate choice," Science Advances 3, no. 3 (2017): 1-8, https://doi.org/10.1126/sciadv.1601990.
} 
Area broca dan wernicke pada perempuan juga lebih luas daripada lakilaki. Kondisi ini menjelaskan fakta bahwa perempuan lebih unggul dalam hal bahasa daripada laki-laki. Bagian dominan otak laki-laki untuk bahasa adalah belahan kiri, sedangkan perempuan dapat menggunakan kedua sisi sesuai dengan konteks bahasa yang memberi stimulus lebih besar.

Berdasarkan pembahasan di atas, dapat diketahui bahwa perbedaan otak perempuan dan laki-laki terletak pada corpus callosum, area broca dan wernicke. Perbedaan ini berlaku secara general (semua perempuan) termasuk para guru PIAUD di TK 'Aisyiyah Nyai Ahmad Dahlan. Mengingat 100\% guru PIAUD di TK 'Aisyiyah Nyai Ahmad Dahlan adalah perempuan, maka dipastikan memiliki corpus callosum yang lebih tebal dan area broca dan wernicke yang lebih laus. Tabel 2 menjelaskan lebih detail perbedaan otak, khususnya corpus callosum dan

Tabel 2.

Perbedaan otak Guru PAUD perempuan di TK Aisyiyah Nyai Ahmad Dahlan

\begin{tabular}{|c|c|c|c|c|c|c|}
\hline \multirow[t]{2}{*}{ Nama Guru } & \multicolumn{2}{|c|}{$\begin{array}{c}\text { Jenis } \\
\text { Kelamin }\end{array}$} & \multicolumn{2}{|c|}{$\begin{array}{l}\text { Corpus } \\
\text { Callosum }\end{array}$} & \multicolumn{2}{|c|}{$\begin{array}{l}\text { Broca dan } \\
\text { Wernicke }\end{array}$} \\
\hline & $\mathrm{L}$ & $\mathrm{P}$ & Tebal & Tipis & Luas & Sempit \\
\hline Nawarol Muniroh, S.TP & - & $v$ & v & - & $v$ & - \\
\hline Ridawati, A. Md. & - & $v$ & 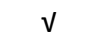 & - & $v$ & - \\
\hline Neti Wuryani & - & $v$ & $v$ & - & $v$ & - \\
\hline Sukraeni, S.Pd.AUD. & - & $v$ & $\checkmark$ & - & $v$ & - \\
\hline Windriyatni, S.Pd. & - & $v$ & $\checkmark$ & - & $v$ & - \\
\hline lid Maida Rais, S.Kh. & - & $v$ & $\checkmark$ & - & $v$ & - \\
\hline Umi Masamah, S.Pd.I. & - & $v$ & $\checkmark$ & - & $v$ & - \\
\hline Laily Widhiastuti, S.Psi. & - & $v$ & $v$ & - & $v$ & - \\
\hline Utami Mayawardhani, S,Si. & - & $v$ & 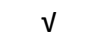 & - & $v$ & - \\
\hline Susi Retnowati, S.Pd. AUD. & - & $\checkmark$ & $\checkmark$ & - & $v$ & - \\
\hline Alfia Trimaylansari, S.Psi. & - & $v$ & $\checkmark$ & - & $v$ & - \\
\hline Anisa Tulhijriyah & - & $v$ & 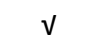 & - & $v$ & - \\
\hline Septiana Abadi, S.Sos.I. & - & $v$ & $\checkmark$ & - & $v$ & - \\
\hline Fardani Atina Yekti, S.Pd.I. & - & $v$ & $\checkmark$ & - & $v$ & - \\
\hline Walijah & - & $v$ & 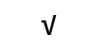 & - & $v$ & - \\
\hline Arroyan Amri Sakinah, S.Sos.I. & - & $v$ & $\checkmark$ & - & $v$ & - \\
\hline Asri Wulandari, S.Pd. & - & $v$ & $\checkmark$ & - & $v$ & - \\
\hline
\end{tabular}


area broca serta wernicke pada perempuan yang berprofesi sebagai guru PIAUD di TKAisyiyah Nyai Ahmad Dahlan tersebut.

Tabel 2 melengkapi Tabel 1 yang sebelumnya menunjukkan bahwa seluruh guru PIAUD TK Aisyiyah Nyai Ahmad Dahlan adalah perempuan. Meskipun ukuran otak perempuan sedikit lebih kecil dari laki-laki tetapi memiliki corpus callosum lebih tebal dan area broca serta wernicke yang lebih luas. Atas dasar ini, dapat dijelaskan bahwa guru PIAUD perempuan di TK Aisyiyah Nyai Ahmad Dahlan meskipun secara kognisi tidak lebih unggul namun secara empatik dan linguistik lebih unggul daripada laki-laki.

Perbedaan otak guru PAUD/PIAUD perempuan ini menarik jika dianalisis dengan teori "netral gender" yang diprediksikan Keohanie. ${ }^{57}$ Ia melihat bahwa dalam beberapa dekade terakhir, tidak seperti masa silam, terdapat puluhan bahkan ratusan perempuan yang masuk posisi paling otoritatif di dunia. Hampir 100 wanita telah terpilih sebagai presiden atau perdana menteri di negara mereka masing-masing sejak 1945, terlebih lagi hanya kepala TK seperti di TK Aisyiyah Nyai Ahmad Dahlan yang juga perempuan.

Penelitian Keohane tersebut bukan berarti bertentangan dengan penelitian Ratnasari yang menyatakan bahwa perempuan lebih empatik. Justru yang terjadi adalah, pemimpin perempuan lebih empatik daripada laki-laki. Meskipun ada bukti bahwa pria dianggap lebih efektif daripada perempuan, tetapi diskursus literatur akademik terbaru menunjukkan bukti keberadaan potensi dan keunggulan kepemimpinan perempuan yang efektif dan empatik tersebut. $^{58}$ Dengan demikian, dapat dipahami bahwa kepala TK Nyai Ahmad Dahlan merupakan pemimpin yang empatik dan efektif.

Dalam perspektif neurosains dan leadership (neuroleadership) sebagaimana diwacanakan Taura Ikrar, kepala dan guru PIAUD perempuan di TK Aisyiyah Nyai Ahmad Dahlan memimpin -baik anak-anak di kelas maupun guru-guru di sekolah- dengan empatik dan efektif menggunakan corpus callosum serta area broca dan wernicke mereka.

\footnotetext{
${ }^{57}$ Nannerl O. Keohane, “The Future of Women's Leadership," Women Leading Change: Case Studies on Women, Gender, and Feminism 1, no. 1 (2016): 4-11, http://journals.tulane.edu/index.php/ ncs/article/view/264.

${ }^{58}$ Samantha C. Paustian-Underdahl, Lisa Slattery Walker, dan David J. Woehr, "Gender and perceptions of leadership effectiveness: A meta-analysis of contextual moderators.," Journal of Applied Psychology 99, no. 6(2014): 1129-45, https://doi.org/10.1037/a0036751.
} 


\section{E. Kesimpulan}

Perempuan mendominasi guru Pendidikan Islam Anak Usia Dini (PIAUD), bahkan TK Aisyiyah Nyai Ahmad Dahlan seluruh (100\%) gurunya adalah perempuan. Sayangnya, guru PIAUD di Indonesia secara umum masih berpendidikan minimalis sebagai guru, yakni S1, berbeda dengan Jepang yang mensyaratkan setiap satu lembaga PAUD harus memiliki guru berkualifikasi doktor (S3).

Perbedaan konstruk budaya antara Indonesia dengan negara-negara maju lainnya, terutama Jepang, menjadikan guru PIAUD Indonesia merasa inlander dari guru pada jenjang dasar dan menengah yang mayoritas laki-laki. Oleh karena itu, pada dasarnya, yang menjadikan bias gender bukanlah perempuan (guru PIAUD) atau laki-laki (guru pada pendidikan dasar dan menengah), melainkan konstruk budaya Indonesia yang belum setara dengan negara lain.

Jika ada rekayasa kebijakan pendidikan yang menggaji guru PIAUD perempuan berkualifikasi doktor (S3) setara bahkan lebih besar daripada dosen di Perguruan Tinggi, maka peneliti berpendapat bahwa konstruk budaya yang selama ini merugikan guru PIAUD perempuan akan pudar.

Secara neurologis otak perempuan memiliki perbedaan daripada otak laki-laki, khususnya corpus callosum yang lebih tebal. Kondisi ini menjadikan perempuan memiliki empati dan kesabaran yang lebih baik daripada laki-laki. Kondisi otak ini membawa konsekensi positif, yakni guru PIAUD perempuan lebih penyabar, empatik dan terampil meregulasi emosi daripada laki-laki.

Perbedaan lainnya adalah area broca dan wernicke pada perempuan lebih luas daripada laki-laki. Kondisi ini menjadikan perempuan lebih banyak bicara, sehingga sesuai dengan masa peka anak usia dini yang juga dalam masa peka bahasa. Konektifitas corpus callosum dan area broca serta wernicke, menjadi guru PIAUD perempuan mampu mendidik dengan bahasa edukatif yang lebih empatik daripada laki-laki.[s]

\section{Daftar Pustaka}

Abidin, Zainal. "Kesetaraan Gender dan Emansipasi Perempuan dalam Pendidikan Islam." Tarbawiyah 12, no. 1 (2008): 1-18. 
Suyadi

Ariany, Lies. "Partisipasi Perempuan di Legislatif Melalui Kuota 30\% Keterwakilan Perempuan di Provinsi Kalimantan Selatan." Jurnal Konstitusi 2, no. 1 (2009): 47-61.

Arsad, Nurazidawati Mohamad. "Peranan Bapak dalam Mewujudkan Keadilan Gender dalam Rumah Tangga: Islam dan Sains." Marwah: Jurnal Perempuan, Agama dan Jender 16, no. 2 (2017): 169-85.

Asmani, Jamal Ma'mur. "Kepemimpinan Perempuan: Pergulatan Wacana di Nahdlatul Ulama (NU)." Addin 9, no. 1 (2015): 33-50.

Bimo, Kak. Mahir Mendongeng. Yogyakarta: Pro-U Media, 2011.

Coates, Jennifer. Women, Men and Language. New York: Routledge Classics, 2016.

Corral-López, Alberto, Natasha I. Bloch, Alexander Kotrschal, Wouter van der Bijl, Severine D. Buechel, Judith E. Mank, dan Niclas Kolm. "Female Brain Size Affects the Assessment of Male Attractiveness during Mate Choice." Science Advances 3, no. 3 (2017): 1-8. https://doi.org/ 10.1126/sciadv.1601990.

Cyprien, Fabienne, Philippe Courtet, Vanessa Poulain, Jerome Maller, Chantal Meslin, Alain Bonafé, Emmanuelle Le Bars, Marie-Laure Ancelin, Karen Ritchie, dan Sylvaine Artero. "Corpus Callosum Size May Predict LateLife Depression in Women: A 10-year Follow-up Study." Journal of Affective Disorders 165, no. August (2014): 16-23. https://doi.org/ 10.1016/j.jad.2014.04.040.

David A. Sousa. Bagaimana Otak Belajar Edisi Keempat. Jakarta: Indeks, 2012.

Denzin, Norman K., dan Yvonna S. Lincoln. Handbook of Qualitative Research. 2 ed. India: Sage Publication. Pvt. Ltd, 1997.

DePoy, Lauren M., dan Shannon L. Gourley. "Synaptic Cytoskeletal Plasticity in the Prefrontal Cortex Following Psychostimulant Exposure." Traffic 16, no. 9 (2015): 919-40. https://doi.org/10.1111/tra.12295.

Desai, Jay, Yuankai Huo, Zhishun Wang, Ravi Bansal, Steven C R Williams, David Lythgoe, Fernando O Zelaya, dan Bradley S Peterson. "Reduced Perfusion in Broca's Area in Developmental Stuttering." Human Brain Mapping 38, no. November (2017): 1865-74. https://doi.org/ 10.1002/hbm.23487. 
Dilla, Siska Chindy, Wahyu Hidayat, dan Euis Eti Rohaeti. "Faktor Gender dan Resiliensi ddalam Pencapaian Kemampuan Berpikir Kreatif Matematis Siswa SMA." Journal of Medives 2, no. 1 (2018): 129-36.

Donald Olding Hebb. "Teori Neurofisiologis Dominan." in Theories of Learning, ed. B.R. Hergenhahn dan Matthew H. Olson. Jakarta: Kencana, 2012.

Guneykaya, Dilansu, Andranik Ivanov, Daniel Perez Hernandez, Verena Haage, Bartosz Wojtas, Niklas Meyer, Meron Maricos, et al. "Transcriptional and Translational Differences of Microglia from Male and Female Brains." Cell Reports 24, no. 10 (2018): 2773-2783.e6. https://doi.org/ 10.1016/j.celrep.2018.08.001.

Heyn, David S, Tony S. Heyn, dan Gabrielle M. D. E. Courten Yers. "Structure of the Cerebral Cortex in Men and Women." Journal of Neuropathology and Experimental Neurology 61, no. 1 (2002): 46-57.

Ikrar, Taruna. Ilmu Neurosains Modern. Yogyakarta: Pustaka Pelajar, 2016.

Ippo 'Right' Santosa. Seri Otak Kanan; 7 Keajaiban Rejeki. Jakarta: PT. Elek Media Komputindo, 2012.

Iqbal, Mahathir Muhammad. "Diskusi Gender dalam Pendidikan Islam." Analisis: Jurnal Studi Keislaman 15, no. 1 (2015): 99-120.

Keohane, Nannerl 0. "The Future of Women's Leadership." Women Leading Change: Case Studies on Women, Gender, and Feminism 1, no. 1 (2016): 4-11. http://journals.tulane.edu/index.php/ncs/article/view/264.

Kotrschal, Alexander, Séverine D. Buechel, Sarah M. Zala, Alberto Corral-Lopez, Dustin J. Penn, dan Niclas Kolm. "Brain Size Affects Female but not Male Survival under Predation Threat." Ecology Letters 18, no. 7 (2015): 646-52. https://doi.org/10.1111/ele.12441.

Kurth, Florian, Lutz Jancke, dan Eileen Luders. "Sexual Dimorphism of Broca' $\mathrm{s}$ Region: More Gray Matter in Female Brains in Brodmann Areas 44 and 45." Journal of Neuroscience Research 95, no. August (2017): 626-32. https://doi.org/10.1002/jnr.23898.

Moleong, Lexy J. Metodologi Penelitian Kualitatif. Bandung: Remaja Rosdakarya, 2014. 
Mustaqim, Yunus. "Pengembangan Konsepsi Kurikulum dalam Pendidikan Islam." Edukasia : Jurnal Penelitian Pendidikan Islam 9, no. 1 (26 Maret 2014): 1-24. https://doi.org/10.21043/edukasia.v9i1.761.

MZ, Zubaidah Amir. "Perspektif Gender dalam Pembelajaran Matematika." Marwah 12, no. 1 (2013): 14-31.

Newman, Sharlene D. "Differences in Cognitive Ability and Apparent Sex Differences in Corpus Callosum Size." Psychological Research 15, no. 3 (2015): 10-15. https://doi.org/10.1007/s00426-015-0688-3.

Novitasari, Dwi. "Analisis Kreativitas Siswa dalam Pemecahan Masalah Visual Spasial dan Logis Matematis Ditinjau dari Gender." Jurnal Media Pendidikan Matematika (JMPM) 5, no. 2 (2017): 151-58.

Nur, Mardin M. "Pengaruh Bias Gender Pembelajaran Pendidikan Agama Islam Terhadap Ketidakadilan Gender di Madrasah Aliyah Ruhul Amin Aceh." Buana Gender 2, no. 2 (2017): 205-25. https://doi.org/10.22515/ bg.v2i2.988.

Taufiq Pasiak. "Pendidikan Karakter sebagai Pendidikan Otak." Dalam Mengatasi Masalah Narkoba dengan Welas Asih. Jakarta: Gramedia Pustaka Utama, 2012.

- - - Tuhan dalam Otak Manusia: Mewujudkan Kesehatan Spiritual Berdasarkan Neurosains. Bandung: Mizan, 2012.

-_- Revolusi IQ/EQ/SQ: Menyingkap Rahasia Kecerdasan Berdasarkan AlQuran dan Neurosains Mutakhir. Bandung: Mizan Bandung, 2008.

Paustian-Underdahl, Samantha C., Lisa Slattery Walker, dan David J. Woehr. "Gender and perceptions of leadership effectiveness: A meta-analysis of contextual moderators." Journal of Applied Psychology 99, no. 6 (2014): 1129-45. https://doi.org/10.1037/a0036751.

Permana, Fitri Yuliantri. "Perempuan dalam Kampanye Antikorupsi." Jurnal Aspikom 3, no. 3 (2016): 399-413.

Purwanti, Kristi Liani. "Perbedaan Gender terhadap Kemampuan Berhitung Matematika Menggunakan Otak Kanan pada Siswa Kelas I." Sawwa: Jurnal Studi Gender 9, no. 1 (2013): 107-22. https://doi.org/10.21580/ SA.V9I1.668. 
Putra, Aris Try Andreas. "Peran Gender dalam Pendidikan Islam." Jurnal Pendidikan Islam 3, no. 2 (2014): 327-43. https://doi.org/10.14421/ jpi.2014.32.325-343.

Ratnasari, Shinantya, dan Julia Suleeman. "Perbedaan Regulasi Emosi Perempuan dan Laki-laki di Perguruan Tinggi." Jurnal Psikologi Sosial 15, no. 1 (2017): 35-46. https://doi.org/10.7454/jps.2017.4.

Snell, Richard S. Clinical Neuroanatomy, 7th Edition. Statistical Science. China, 2010.

Suyadi. "Dasar-dasar Pemikiran menuju Ilmu Neurosains Pendidikan Islam (Optimalisasi Potensi Otak dalam Pembelajaran Anak Usia Dini)." Disertasi. Pascasarjana UIN Sunan Kalijaga, 2016. http://digilib.uinsuka.ac.id/19927/.

—_—. Psikologi Belajar PAUD. Yogyakarta: Pedagogia, 2009.

_-_ Teori Pembelajaran Anak usia Dini dalam Kajian Neurosains. Bandung: Rosda Karya, 2016.

Suyadi, dan Dahlia. Implementasi dan Inovasi Kurikulum PAUD 2013. Bandung: Rosda Karya, 2014.

Suyadi, dan Imam Zarkasih Putro. Bimbingan dan Konseling Pendidikan Anak Usia Dini (BK-PAUD). Bandung: Remaja Rosdakarya, 2016.

Suyadi, dan Maulidya Ulfa. Konsep Dasar PAUD. Bandung: Remaja Rosdakarya, 2013.

Tafsir, Ahmad. Ilmu Pendidikan dalam Perspektif Islam. Revisi. Bandung: Remaja Rosdakarya, 2014.

Tarbawiyahrapto, Siti Zubaidah, Aloysius Durun Corebima. "Pengaruh Gender terhadap Keterampilan Berpikir Kreatif Siswa pada Pembelajaran Biologi." Jurnal Pendidikan: Teori, Penelitian, dan Pengembangan 3, no. 3 (2018): 325-29.

Tim Penyusun. Profil TK Aisyiyah Nyai Ahmad Dahlan Full Day. Yogyakarta: Aisyiyah, 2018.

Toga, Arthur W, dan Paul M Thompson. "Mapping Brain Asymmetry." Nature Review Neuroscience 4, no. January (2003): 33-46. https://doi.org/ 10.1038/nrn1009. 
Suyadi

Vries, Geert J De, dan Nancy G Forger. "Sex Differences in the Brain: A Whole Body Perspective." Biology of Sex Differences 5, no. 15 (2015): 1-15. https://doi.org/10.1186/s13293-015-0032-z.

William Crain. Teori Perkembangan, Konsep dan Aplikasi, terj. Yudi Santoso. Yogyakarta: Pustaka Pelajar, 2007.

Zilfa, Rohil. "Telaah Komparatif Pengarusutamaan Gender dalam Pendidikan Islam di Saudi Arabia, Mesir, Malaysia, dan Indonesia." Jurnal Pendidikan Agama Islam 5, no. 2 (2017): 264-87. 